\title{
Quantification of $\beta$-carotene, lycopene, and chlorophyll content in tomato fruits of enrichment of chicken feathers composting
}

\author{
Mohan Arthanari ${ }^{1}\left[\mathbb{D} \cdot\right.$ Senthilkumar Dhanapalan ${ }^{1}[\mathbb{C}$
}

Received: 16 July 2018 / Accepted: 16 March 2019 / Published online: 25 March 2019

(c) The Author(s) 2019

\begin{abstract}
Purpose Chicken feather was thrown into the environments, which causes health hazards and environmental pollution. It contains large number of proteins which can be converted into organic fertilizer to reduce the pollution load. These will help to minimize the protein needs and maintain low cost for utilization as raw material for manure production.

Methods Chicken feather waste was subjected to composting by mixing it with cow dung and agricultural waste. Four different composts were prepared for composting of the chicken feather waste: $E_{1}, E_{2}, E_{3}$, and $E_{4}$, along with a control [cow dung $(\mathrm{CW})+$ agricultural waste $(\mathrm{AG})$ ]. The major and minor nutrient contents of the compost were analyzed on the 90 th day. The prepared compost was applied to Solanum lycopersicum plants; fruits pigments (lycopene, $\beta$-carotene, and chlorophyll) were evaluated.

Result Chicken feather compost has high nutrient level organic carbon (1.83\%), nitrogen (7.33\%), potassium (4.40\%), sulphur (19.69 ppm), zinc (4.96 ppm), boron $(0.59 \mathrm{ppm})$, and iron $(6.62 \mathrm{ppm})$ except phosphorus $(0.26 \%)$ in the control. Results revealed highest lycopene in $\mathrm{E}_{4}(0.5881 \mathrm{mg} / 100 \mathrm{ml})$ and $\beta$-carotene in $E_{1}(0.2699 \mathrm{mg} / 100 \mathrm{ml})$ when compared with the control value lycopene $(0.4602 \mathrm{mg} / 100 \mathrm{ml})$ and $\beta$-carotene $(0.1341 \mathrm{mg} / 100 \mathrm{ml})$. A positive correlation has been established between lycopene/ $\beta$-carotene and negative correlation have been existing chlorophyll content vs lycopene/ $\beta$-carotene. Conclusion Chicken feather can be eco-friendly when converted into compost which in turn enriches the quality of tomato fruits (lycopene and $\beta$-carotene).
\end{abstract}

Keywords $\beta$-Carotene $\cdot$ Lycopene $\cdot$ Total chlorophyll $\cdot$ Chlorophyll a and $b$

\section{Introduction}

Poultry farms produce a lot of different types of waste products, such as fecal excreta, bedding material, remaining feed, departed chickens, damaged eggs, and packing materials. Kelleher et al. (2002) stated that poultry wastes are also found in conveyor belts, cleaning systems and carrying materials. Globally, 8.5 billion tons of feathers are generated annually, with approximately 350 million tons generated in India alone (Agrahari and Wadhwa 2010). This poultry feather meal is a readily available and low-cost source of nitrogen (up to $15 \% \mathrm{~N}$ ) and functions as a potential biofertilizer (Jeong et al. 2010). Poultry feathers are animal byproducts with high protein content, which contain leucine,

Mohan Arthanari

elur.mohan@gmail.com

1 Department of Zoology, Kandaswami Kandar's College, Namakkal, Tamil Nadu, India valine, arginine, isoleucine, phenylalanine, and threonine, but with smaller proportions of lysine, methionine, histidine, and tryptophan (Yokote et al. 2007; Bandegan et al. 2010). The macro- and micronutrients present in the chicken feather waste-compost retain the inorganic fertilizer (Kalaivanan and Hattab 2016), it also improved the physicochemical and biological properties of the soil (Adhami et al. 2014; Lim et al. 2015). A huge volume of chicken feather waste causes environmental problems, contaminates air, water, and soil ecosystem. Soil microbes, in turn, ferment them into organic nitrogen and may be utilized for agricultural purposes (Paul et al. 2018).

Tomato (Solanum lycoperscium) is a major vegetable crop and commonly cultivated worldwide. Lycopene is one of the major (90\%) important natural carotenoids found in tomato, which is the main pigment that gives the red color to tomatoes (Shi et al. 1999). Carotenoids, such as $\beta$-carotene and lycopene, are important components of antioxidant defense against lipid peroxidation in living cells (Agarwal 
et al. 2005). Lycopene contains unsaturated acyclic carotenoid, with 11 conjugated double bonds that act as effective free radical scavengers (Shi and Maguer 2000). Carotenoids are important dietary sources of vitamin $\mathrm{A}$, after $\beta$-carotene retinol bioconversion into pro-vitamin A (Tang 2010). The objective of this present research work was to manage chicken feather-waste through a mixture of aerobic decomposition processes. The influence of treated chicken feather wastes on the tomato fruits $\beta$-carotene, lycopene, and chlorophyll contents, and estimation of chicken feathers waste to be used as organic nitrogen enriched fertilizers.

\section{Materials and methods}

\section{Collection of raw materials}

Chicken feather (CF) waste has been collected from slaughterhouses in Elur village, Namakkal District of Tamil Nadu. The agricultural waste and cow dung were also collected from the same place. The collected CF were washed in tap water several times, sun-dried, cut into small pieces and utilized for compost experiments.

\section{Experimental setup}

Five circular containers ( $25 \mathrm{~cm}$ diameter and $40 \mathrm{~cm}$ height) had the raw materials (CD:AW:CF) and were mixed in a different ratios $\mathrm{C}(4: 4: 0), E_{1}(4: 4: 1), E_{2}(4: 4: 2), E_{3}(4: 4: 3)$, and $E_{4}$ (4:4:4). The compost was maintained at $40-60 \%$ moisture level throughout the experimental period (90 days).

\section{Physico-chemical analysis}

$\mathrm{pH}$ of compost samples was determined using a double $\mathrm{DH}_{2} \mathrm{O}$ suspension of compost in the ratio of $1: 10(\mathrm{w} / \mathrm{v})$ analyzed in Digital pH meter (Vasanthi et al. 2014), the total organic carbon (TOC) content was estimated using the method of Abdullah and Chin (2010). Total Nitrogen (TN) was estimated by Micro Kjeldahl method (Mohee et al. 2008; Unmar and Mohee 2008). Total Phosphorus (TP) was detected by the colorimetric method (John 1970). Total potassium (TK) was determined after digesting the sample in diacid mixture (concentrated $\mathrm{HNO}_{3}$; concentrated $\mathrm{HCIO}_{4}$, 4:1, v/v), by Flame Photometer (Bansal and Kapoor, 2000). Sulfur (S), zinc (Z), boron (B), and iron (Fe) were measured by the diacid digest using an atomic absorption spectrophotometer (Vasanthi et al. 2014).

\section{Biochemical analysis of fruit pigments}

$1 \mathrm{~g}$ of tomato fruit was homogenized with (10-20 ml) of acetone-hexane (4:6) solvent. After homogenization, the supernatant was used for the biochemical analysis (Nagata and Yamashita 1992).

\section{Quantification of lycopene, $\beta$-carotene, and chlorophyll}

The content of lycopene, $\beta$-carotene, and chlorophyll was determined based on a spectrophotometric analysis according to the method described by Mackinney's method and Kimura's method. Lycopene, $\beta$-carotene, and chlorophyll a, $\mathrm{b}$, and total contents were expressed as $\mathrm{mg} / 100 \mathrm{ml}$.

\section{Statistical analysis}

Statistical analysis was performed and the data were compared using one-way ANOVA, Tukey's HSD (honestly significant difference) and DMRT (Duncan multiple range test) in SPSS (version 21), Pearson-Correlation Matrix and Visualization-correlation matrix in R-STHDA (statistical tools for high-throughput data analysis).

\section{Results and discussion}

The results of the physicochemical test of the final products are presented in Table 1 . The $\mathrm{pH}$ is one of the important characteristics of the composting process; the chicken feathers' compost was highly alkaline $(\mathrm{pH}>8.60)$. The chicken feathers composting occurs in a strongly alkaline

Table 1 Physicochemical parameter of feather compost samples

\begin{tabular}{llllllllll}
\hline Samples & $\mathrm{pH}$ & $\mathrm{OC}(\%)$ & $\mathrm{N}(\%)$ & $\mathrm{P}(\%)$ & $\mathrm{K}(\%)$ & $\mathrm{S}(\mathrm{ppm})$ & $\mathrm{Zn}(\mathrm{ppm})$ & $\mathrm{B}(\mathrm{ppm})$ & $\mathrm{Fe}(\mathrm{ppm})$ \\
\hline Control & $8.32 \pm 0.29^{\mathrm{c}}$ & $0.84 \pm 0.57^{\mathrm{d}}$ & $1.23 \pm 0.49^{\mathrm{e}}$ & $0.26 \pm 0.13^{\mathrm{a}}$ & $2.76 \pm 0.78^{\mathrm{e}}$ & $14.79 \pm 1.06^{\mathrm{d}}$ & $1.77 \pm 0.58^{\mathrm{d}}$ & $0.41 \pm 0.15^{\mathrm{e}}$ & $10.60 \pm 1.96^{\mathrm{b}}$ \\
$E_{1}$ & $8.26 \pm 0.99^{\mathrm{d}}$ & $0.51 \pm 0.08^{\mathrm{e}}$ & $2.25 \pm 0.74^{\mathrm{d}}$ & $0.14 \pm 0.07^{\mathrm{e}}$ & $2.89 \pm 1.01^{\mathrm{d}}$ & $19.69 \pm 1.08^{\mathrm{a}}$ & $4.96 \pm 0.80^{\mathrm{a}}$ & $0.59 \pm 0.16^{\mathrm{a}}$ & $15.53 \pm 0.88^{\mathrm{a}}$ \\
$E_{2}$ & $8.60 \pm 1.16^{\mathrm{a}}$ & $1.73 \pm 1.11^{\mathrm{b}}$ & $7.33 \pm 1.21^{\mathrm{a}}$ & $0.16 \pm 0.05^{\mathrm{b}}$ & $3.82 \pm 0.90^{\mathrm{b}}$ & $14.55 \pm 0.07^{\mathrm{e}}$ & $1.81 \pm 0.69^{\mathrm{b}}$ & $0.45 \pm 0.10^{\mathrm{d}}$ & $5.20 \pm 1.02^{\mathrm{e}}$ \\
$E_{3}$ & $8.09 \pm 1.33^{\mathrm{e}}$ & $1.83 \pm 1.14^{\mathrm{a}}$ & $6.75 \pm 0.89^{\mathrm{b}}$ & $0.14 \pm 0.01^{\mathrm{d}}$ & $4.40 \pm 1.30^{\mathrm{a}}$ & $15.80 \pm 2.49^{\mathrm{c}}$ & $1.82 \pm 0.19^{\mathrm{c}}$ & $0.52 \pm 0.29^{\mathrm{b}}$ & $6.00 \pm 2.55^{\mathrm{d}}$ \\
$E_{4}$ & $8.37 \pm 1.33^{\mathrm{b}}$ & $1.55 \pm 0.87^{\mathrm{c}}$ & $6.35 \pm 0.04^{\mathrm{c}}$ & $0.15 \pm 0.08^{\mathrm{c}}$ & $3.62 \pm 1.52^{\mathrm{c}}$ & $16.80 \pm 1.92^{\mathrm{b}}$ & $1.40 \pm 0.94^{\mathrm{e}}$ & $0.51 \pm 0.14^{\mathrm{c}}$ & $6.62 \pm 1.12^{\mathrm{c}}$ \\
\hline
\end{tabular}

Mean values designated with different superscripts indicate that differences between treatment are significant according to the Tukey's HSD (honestly significant difference) and DMRT (Duncan multiple range test) $(P<0.05)$ 
environment during the process which causes the inactivation of the pathogens in the feathers compost (Tronina and Bubel 2008). The maximum available nitrogen content in $E_{2}$ was $7.33 \%$, which is consistent with the findings of Jeong et al. 2010. Nitrogen serves as an essential component of amino acid, the basic structural unit of proteins. Here the significant decrease in the nitrogen content of the compost was resultant of the ammonification process, which converted a fraction of organic $\mathrm{NH}_{3}$ into $\mathrm{NH}^{4+}$ ions (Tiquia, 2002). Phosphorus provided energy for plant growth and maintains the equilibrium of plant (McWilliams 2003). The feather compost contains phosphorus which is lesser than the control in our present study $(0.26 \%)$. Phosphorus enhances the chlorophyll level in the plants. An elevated potassium (K) level was recorded in $E_{3}(4.40 \%)$. Wool and hair waste has a nutrient source $(\mathrm{N}, \mathrm{P}, \mathrm{K}$, and $\mathrm{S})$ for crops and potential to improve soil biology and chemical properties (Valtcho and Zheljazkov 2005). The maximum of micronutrients was present in $E_{1}$ compost: S $19.69 ; \mathrm{Zn} \mathrm{4.96;} \mathrm{B} 0.59$ and Fe $15.53 \mathrm{ppm}$. The requirement of micronutrients is negligible and it may affect plant growth. Most of the micronutrient is present either in Fe form or as chelated EDTA in the metabolism (McWilliams 2003).

The pigment composition of tomato fruit was determined and the data are recorded in Table 2. The results revealed highest lycopene content recorded as $E_{4}(0.5881 \mathrm{mg} / 100 \mathrm{ml}), E_{3}(0.5803 \mathrm{mg} / 100 \mathrm{ml}), E_{2}$ $(0.5773 \mathrm{mg} / 100 \mathrm{ml}), E_{1}(0.5388 \mathrm{mg} / 100 \mathrm{ml})$ and lowest in $\mathrm{C}(0.4602 \mathrm{mg} / 100 \mathrm{ml})$. Mendelova et al. (2013), found that supplemental nutrition by increased sulfur content was manifested by higher lycopene content in fruits by $44.5 \%$ for a tomato variety. High level of $\beta$-carotene was present in $E_{1^{-}}$ treated plants and the level was reduced towards the control plant $\left[E_{1}(0.2699 \mathrm{mg} / 100 \mathrm{ml}), E_{3}(0.2681 \mathrm{mg} / 100 \mathrm{ml}), E_{4}\right.$ $(0.2575 \mathrm{mg} / 100 \mathrm{ml}), E_{2}(0.2699 \mathrm{mg} / 100 \mathrm{ml})$ and control $(0.1341 \mathrm{mg} / 100 \mathrm{ml})]$. Huang et al. (2010) observed the content of lycopene and $\beta$-carotene in tomato sauce and ketchup. The tomato fruits emerging from the control plants exhibit maximum level of chlorophyll (a) $0.0518 \mathrm{mg} / 100 \mathrm{ml}$ and total chlorophyll $0.0904 \mathrm{mg} / 100$, whereas chlorophyll (b) in $E_{1}$ was $0.0466 \mathrm{mg} / 100 \mathrm{ml}$.

\section{Correlation matrix}

To determine the relationships among the analyzed traits, a Pearson correlation matrix analysis was performed as shown in Table 3. A high positive correlation was established between lycopene and $\beta$-carotene $\left(r=0.9^{*}\right)$, and negative correlation against chlorophyll contents (lycopene $r=-0.55,-0.98 * *$ and $-0.87 ; \beta$-carotene $r=-0.19,-0.8$ and -0.59$)$. A positive correlation was found within the chlorophyll content of tomato fruits with a high positive correlation coefficient $(r=0.94 *)$ between total chlorophyll and chlorophyll (a). Visualization of the correlation matrix was plotted using corrplot package. In Correlogram Fig. 1, the positive and negative correlations are displayed in blue and red color. Correlation coefficients were detected by the proportion of color intensity and size of the circle. The positive
Table 2 Analysis of plant pigments lycopene, $\beta$-carotene, and chlorophyll

\begin{tabular}{llllll}
\hline Experiment & $\begin{array}{l}\text { Lycopene } \\
(\mathrm{mg} / 100 \mathrm{ml})\end{array}$ & $\begin{array}{l}\beta \text {-Carotene } \\
(\mathrm{mg} / 100 \mathrm{ml})\end{array}$ & $\begin{array}{l}\text { Chlorophyll (a) } \\
(\mathrm{mg} / 100 \mathrm{ml})\end{array}$ & $\begin{array}{l}\text { Chlorophyll (b) } \\
(\mathrm{mg} / 100 \mathrm{ml})\end{array}$ & $\begin{array}{l}\text { Total chlo- } \\
\text { rophyll } \\
(\mathrm{mg} / 100 \mathrm{ml})\end{array}$ \\
\hline Control & 0.4602 & 0.1341 & 0.0518 & 0.0386 & 0.0904 \\
$E_{1}$ & 0.5388 & 0.2699 & 0.0343 & 0.0466 & 0.0809 \\
$E_{2}$ & 0.5773 & 0.2519 & 0.0159 & 0.0139 & 0.0298 \\
$E_{3}$ & 0.5803 & 0.2681 & 0.0177 & 0.0342 & 0.0519 \\
$E_{4}$ & 0.5881 & 0.2575 & 0.0114 & 0.0241 & 0.0355 \\
\hline
\end{tabular}

Table 3 Correlation matrix of lycopene, $\beta$-carotene and chlorophyll

\begin{tabular}{llllll}
\hline & Lycopene & $\beta$-Carotene & Chlorophyll B & Chlorophyll A & $\begin{array}{l}\text { Total } \\
\text { chloro- } \\
\text { phyll }\end{array}$ \\
\hline Lycopene & 1 & 1 & & \\
$\beta$-Carotene & $0.9^{*}$ & -0.55 & -0.19 & 1 & \\
Chlorophyll B & $-0.98^{* *}$ & -0.8 & 0.67 & 1 \\
Chlorophyll A & $-0.99^{*}$ & $0.94^{*}$ & 1 \\
Total chlorophyll & -0.87 & -0.59 & 0.89 & \\
\hline
\end{tabular}

*Correlation is significant at the 0.05 level

**Correlation is significant at the 0.01 level 


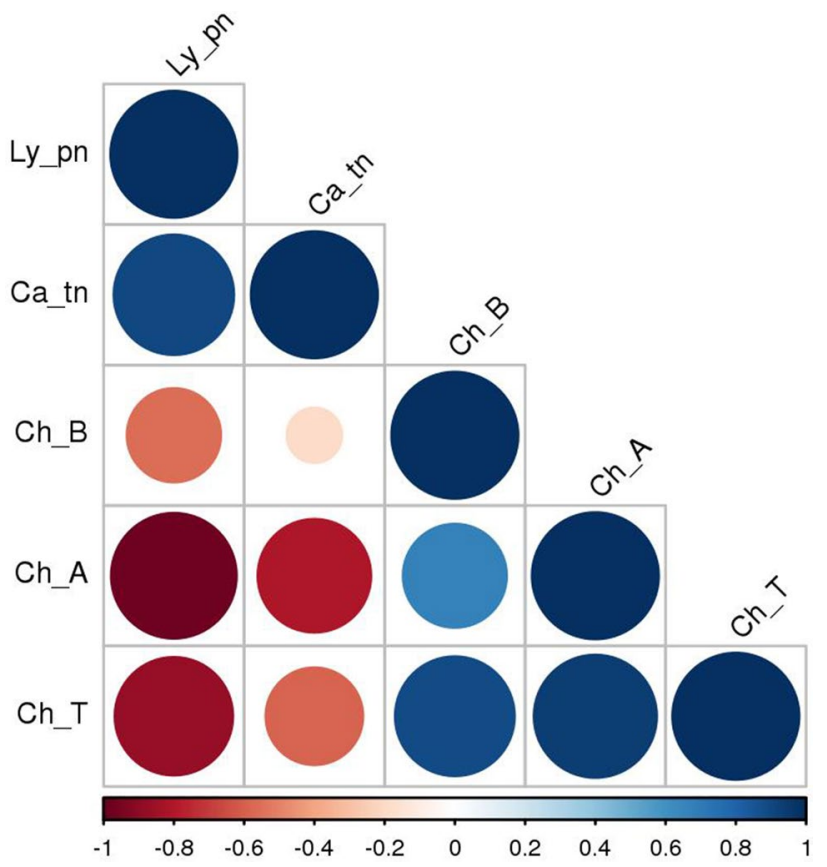

Fig. 1 Correlogram. $L y \_p n$ lycopene, $C a \_t n \beta$-carotene, $C h \_B$ chlorophyll b, $C h \_A$ chlorophyll a, $C h \_T$ total chlorophyll

correlation between total chlorophyll and chlorophyll A highly correlated in the blue color circle. Chlorophyll A and lycopene are mostly negatively correlated with the red color circle. No correlation was established between lycopene and total chlorophyll.

\section{Conclusion}

Based on the result obtained, we can conclude that the various compost mixtures exhibit statistical significance among pigments of tomato fruits. The highest content of $\beta$-carotene and lycopene was observed in $E_{1}$ and $E_{5}$ tomato fruits.

Open Access This article is distributed under the terms of the Creative Commons Attribution 4.0 International License (http://creativeco mmons.org/licenses/by/4.0/), which permits unrestricted use, distribution, and reproduction in any medium, provided you give appropriate credit to the original author(s) and the source, provide a link to the Creative Commons license, and indicate if changes were made.

\section{References}

Abdullah N, Chin NL (2010) Simplex-centroid mixture formulation for optimized composting of kitchen waste. Bioresour Technol. 101(21):8205-8210. https://doi.org/10.1016/j.biort ech.2010.05.068
Adhami E, Hosseini S, Owliaie H (2014) Forms of phosphorus of vermicompost produced from leaf compost and sheep dung enriched with rock phosphate. Int J Recycl Org Waste Agric 3:68. https:// doi.org/10.1007/s40093-014-0068-9

Agarwal A, Prahakaran SA, Said TM (2005) Prevention of oxidative stress injury to sperm. J. Androl 26:653-660. https://doi. org/10.2164/jandrol.05016

Agrahari S, Wadhwa N (2010) Degradation of chicken feather a poultry waste product by keratinolytic bacteria isolate from dumping site at Ghazipur poultry processing plant. Int J Poult Sci 9:482-489. https://doi.org/10.3923/ijps.2010.482.489

Bandegan A, Kiarie E, Payne RL, Crow GH, Guenter W, Nyachoti CM (2010) Standardized ileal amino acid digestibility in dry-extruded expelled soybean meal, extruded canola seed-pea, feather meal, and poultry by-product meal for broiler chickens. Poult Sci. 89:2626-2633. https://doi.org/10.3382/ps.2010-00757

Bansal S, Kapoor KK (2000) Vermicomposting of crop residues and cattle dung with Eisenia foetida. Bioresour Technol. 73:95-98. https://doi.org/10.1016/S0960-8524(99)00173-X

Huang XY, Liu YW, Di DL, Liu JX, Li C (2010) An Improved LCDAD method for simultaneous determination of lutein, b-carotene and lycopene in tomato and its products. Chromatographic 71(3/4):331-334. https://doi.org/10.1365/s10337-009-1417O(ISSN: 0009-5893)

Jeong JH, Lee OM, Jeon YD, Kim JD, Lee NR, Lee CY, Son HJ (2010) Production of keratinolytic enzyme by a newly isolated feather degrading Stenotrophomonas maltophilia that produces plant groth promoting activity. Process Biochem 45:1738-1745. https ://doi.org/10.1016/j.procbio.2010.07.020

John MK (1970) Colorimetric determination of phosphorus in soil and plant material with ascorbic acid. Soil Sci 109:214-220. https:// doi.org/10.1097/00010694-197004000-00002

Kalaivanan D, Hattab KO (2016) Recycling of sugarcane industries byproducts for preparation of enriched press mud compost and its influence on growth and yield of rice (Oryza sativa $\mathrm{L}$ ). Int $\mathbf{J}$ Recycl Org Waste Agric 5:263-272. https://doi.org/10.1007/s4009 3-016-0136-4

Kelleher BP, Leahy JJ, Henihan AM, O’Dwyer TF, Sutton D, Leahy MJ (2002) Advance in poultry litter disposal technology. Bioresour Technol 83(1):27-36. https://doi.org/10.1016/S0960 -8524(01)00133-X

Lim SL, Wn TY, Lim PN, Shak KPY (2015) The use of vermicompost in organic farming: overview, effects on soil and economics. J Sci Food Agric 95(6):1143-1156. https://doi.org/10.1002/jsfa.6849

Mc William D (2003) Identifying nutrient deficiencies for efficient plant growth and water use. Co-operative extensive services college of agriculture and home economics

Mendelova A, Flkselova M, Mendel L (2013) Carotenoids and Lycopene content in fresh and dried tomato juice. Acta Universitatis Agriculturae et Silviculturae Mendelianae Brunensis 5:1329_ 1337. https://doi.org/10.11118/actaun201361051329

Mohee R, Driver MFB, Sobratee N (2008) Transformation of spent broiler litter from exogenous matter to compost in a sub-tropical context. Bioresour Technol. 99(1):128-136. https://doi. org/10.1016/j.biortech.2006.11.040

Nagata M, Yamashita I (1992) A simple method for simultaneous determination of chlorophyll and carotenoids in tomato fruit. J Jpn Soc Food Sci Technol 39(10):925-928. https://doi.org/10.3136/ nskkk1962.39.925

Paul T, Mandal A, Mondal KC (2018) Waste to value aided fertilizer: an alternative cleaning technique for poultry feathers waste disposal. Ann Microbiol Immunol 1(2):1006

Shi J, Le Maguer M, Kakuda Y, Liptay A, Niekamp F (1999) Lycopene degradation and isomerization in tomato dehydration. Food Res Int 32:15-21. https://doi.org/10.1016/S0963-9969(99)00059-9 
Shi J, Maguer M (2000) Lycopene in tomatoes: chemical and physical properties affected by food processing. Crit Rev Biotechnol 20:293-334. https://doi.org/10.1080/07388550091144212

Tang G (2010) Bioconversion of dietary provitamin A carotenoids to vitamin A in human. Am J Clin Nutr 91:148S-1473S. https://doi. org/10.3945/ajen.2010.28674G

Tiquia SM (2002) Evaluation of organic matter and nutrient composition of partially decomposed and composed and composted spent pig litter. Environ Technol 24:97-107

Tronina P, Bubel F (2008) Production of organic fertilizer from poultry feather wastes excluding the composting process. Polish J Chem Technol 10(2):33-36. https://doi.org/10.2478/v10026-008-0025-3

Unmar G, Mohee R (2008) Assessing the effect of biodegradable and degradable plastics on the composting of green wastes and compost quality. Bioresour Technol 99(1):6738-6744. https://doi. org/10.1016/j.biortech.2008.01.016

Vasanthi K, Chairman K, Ranjit Singh AJA (2014) Sugar factory waste vermicomposting with an epigeic earthworm, Eudrilus eugeniae (Kinberg). Am J Drug Discov Dev 4:22-31. https://doi. org/10.3923/ajdd.2014.22.31

Yokote Y, Kubo Y, Takahashi R, Ikeda T, Akahane K, Tsuboi M (2007) Structural details of a fowl feather elucidated by using polarized Raman microspectroscopy. Chem Soc Jpn 80:1148-1156. https:// doi.org/10.1246/bcsj. 80.1148

Zheljazkov DV (2005) Assessment of wood waste and hair waste as a soil amendment and nutrient source. J Environ Qual 34:2310 2317. https://doi.org/10.2134/jeq2004.0332

Publisher's Note Springer Nature remains neutral with regard to jurisdictional claims in published maps and institutional affiliations. 